\begin{tabular}{|c|c|c|c|}
\hline $\begin{array}{l}\text { RESEARCH } \\
\text { ARTICLE }\end{array}$ & $\begin{array}{r}\text { ADVANCE RESEARCF } \\
\text { Volume } 9 \mid \text { Issue } 2 \mid \text { De }\end{array}$ & $\begin{array}{l}\text { OCIAL SCIENCE } \\
-0976-5611\end{array}$ & \\
\hline $0=$ & DOI: 10.15740/HAS/ARJSS/9.2/242-245 & Visit us : www.researchjournal.co.in & \\
\hline
\end{tabular}

\title{
A study on health status of elderly male and female in rural area
}

Anshu* and Reena Rawal

Department of Extension Education and Communication Management, I.C. Collage of Home Science, C.C.S. Haryana Agricultural Univesity, Hisar (Haryana) India

Email : anshugahlawat3@gmail.com

\section{ARTICLE INFO :}

$\begin{array}{lll}\text { Received } & : & 22.10 .2018 \\ \text { Revised } & : & 20.11 .2018 \\ \text { Accepted } & : & 23.11 .2018\end{array}$

KEY WORDS :

Old age, Stress, Man, Women

HOW TO CITE THIS ARTICLE :

Anshu and Rawal Reena (2018). A study on health status of elderly male and female in rural area. Adv. Res. J. Soc. Sci., 9 (2) : 242-245, DOI: 10.15740/HAS/ARJSS/ 9.2/242-245.

Copyright@2018 : Hind Agri -

Horticultural Society

*Author for correspondence

\begin{abstract}
The study was conducted in landhari village of Hisar district, Haryana purposely. Total 50 respondents were selected randomly from village 25 male and 25 female with the objective to study the health status of elderly and find out the preventive measure followed. Health is not only a biological or medical concern but also a significant personal and social concern. Gender wise differences were found in the health status of the elderly respondents. Compared to men, the health status of women was found to be poor. This might be due to under nourishment associated with cultural practices in India especially in rural areas. Women in rural areas, generally take meals only after their husbands and children have had their food.
\end{abstract}

